\title{
Marine Protected Areas and marine spatial planning for the benefit of marine mammals
}

\author{
PETER G.H. EVANS ${ }^{1,2}$ \\ ${ }^{1}$ Sea Watch Foundation, Ewyn y Don, Bull Bay, Amlwch, Anglesey LL68 9SD, UK, ${ }^{2}$ School of Ocean Sciences, University of Bangor, \\ Menai Bridge, Anglesey LL59 5AB, UK
}

The world's oceans, that make up more than $70 \%$ of the earth's surface, face a wide range of human pressures (Halpern et al., 2008, 2015). This applies particularly to the coastal zone (Ramesh et al., 2015), where marine mammal communities in almost $50 \%$ of the world's coastal waters are considered at high-risk (Avila et al., 2018). One means of tackling conservation pressures facing marine species has been to establish Marine Protected Areas (Gubbay, 1995; Kelleher et al., 1995; Agardy, 1997; Gjerde \& Breide, 2003; Edgar et al., 2014), although, as yet, these apply to only $5 \%$ of the world's seas (UNEP-WCMC, IUCN, 2016).

The first Marine Protected Area (MPA) for cetaceans was established in 1971 in Laguna Ojo de Liebre, otherwise known as Scammon's Lagoon, in Baja California, Mexico to protect the winter breeding grounds of the gray whale (Eschrichtius robustus). Forty years later, there were at least 650 protected areas which included marine mammals (Hoyt, 2011). However, many of these were not established specifically for marine mammals, and have no detailed management measures targeting them. Even when supposedly designated for them (e.g. the Irish Whale \& Dolphin Sanctuary), they provide little in the way of specific conservation measures. On the other hand, if implemented properly, they can be effective, as shown for example in the case of the Banks Peninsula Marine Mammal Sanctuary in New Zealand, which appears to have been successful in enabling the local population of the endangered Hector's dolphin to increase by $6 \%$ per annum (Gormley et al., 2012). Although frequently not followed, there have been a number of attempts to provide guidelines for how to make MPAs effective (Kelleher, 1999; Roberts \& Hawkins, 2000; Salm \& Clark, 2000; Agardy, 2010), including some focused upon MPAs for marine mammals (Reeves, 2000; Hooker \& Gerber, 2004; Evans, 2008; Hooker et al., 2011; Hoyt, 2011; Notarbartolo di Sciara et al., 2016).

Marine mammal scientists and practitioners are divided over the value of establishing MPAs generally for such a mobile group as cetaceans (see, for example, Reeves, 2000;

Corresponding author:

P.G.H. Evans

Email: peter.evans@bangor.ac.uk
Evans, 2008; Notarbartolo di Sciara et al., 2016; Wilson, 2016; Hoyt, 2017), and it is often argued that focusing upon the particular anthropogenic pressures/stressors rather than setting boundaries around specific areas may be more effective for those species that do not have discrete identifiable home ranges. The strengths and limitations of each approach are summarized in Table 1 . It is likely that conservation can best be achieved by integrating both approaches.

Most MPAs are small, and do not encompass the feeding or breeding hotspots (often referred to as 'critical habitat') of these highly mobile species. In the past, we have been limited by our lack of knowledge of where these are and the ecological factors shaping their importance, but with more extensive survey effort combined with ever more sophisticated habitat modelling approaches, in some of the more accessible regions at least, this no longer applies (see, for example, Kaschner et al., 2006; Hooker et al., 2011).

The need for increasing the size of protected areas to form a network embracing critical habitats has formed the basis of the European Union's Habitats \& Species Directive's Natura 2000 network of Special Areas of Conservation (SACs) across Europe. It is applied to just a few marine mammal species: harbour porpoise (Phocoena phocoena), bottlenose dolphin (Tursiops truncatus), Atlantic grey seal (Halichoerus grypus), harbour seal (Phoca vitulina), ringed seal (Phoca hispida) and Mediterranean monk seal (Monachus monachus), and there are obvious species that could have been included but are not, for example white-beaked dolphin (Lagenorhynchus albirostris), Risso's dolphin (Grampus griseus) and minke whale (Balaenoptera acutorostrata). Member states have been slow to designate SACs, and even where established, very few possess management plans designed to protect those species let alone ones that are fully enforced. Furthermore, there has been no real attempt as yet to develop protective measures in an integrated and cooperative manner across the network, taking account of issues relating to biological connectivity.

In most cases, management within MPAs allows for multiple use. This is the case, for example, within the Special Areas of Conservation created under the European Union Habitats \& Species Directive. However, this can result in tensions between conservation interests and other marine stakeholders who press to use those areas for their own interests and livelihoods. 
Table 1. The strengths and limitations of area-based $v s$ issue-based conservation measures.

Area-based conservation measures

\section{Pros}

Cons

Provides focus to areas/habitats that are of particular importance for the species

Some features of the ocean (e.g. bathymetry, high energy sites) are stable over time, thus affording favourable conditions which may be applicable to a variety of species

Many human activities (e.g. recreation, seismic, offshore renewables) are area-based

Encourages developers to conduct fuller HRAs/EIAs before starting activities

Encourages development of a management plan involving all users

Raises public awareness and conservation focus for the species in that area

Those important areas may change over time; requires adaptive management

If environmental conditions do vary, area-based legislation traditionally takes time to respond

Fishing activities in particular tend to move around

Boundaries have to be meaningful

Can lead to conflicts between users and regulators/conservation groups

If the species occurs significantly outside that area, those regions may receive less attention

\section{Pressure-based conservation measures}

Can be designed to target particular human pressures wherever they occur

Conservation measures can be expensive; so with limited resources, often a need to target areas where potential conflict will be greatest

Provides greater focus upon issue-based mitigation measures, e.g. net modification, bubble curtains

Since fisheries move around as do their target prey, it is difficult to regulate within the confines of a particular area whereas measures can be introduced throughout a fishery

Although pollutant point sources can effectively be managed spatially, pollutants disperse over wide areas and so are not easily controlled by area-based measures

The most effective management measure may simply be to ensure that cetaceans and the conflicting activity are separated in space and time

The establishment of some safe havens for fish may not only benefit top predators like cetaceans and seabirds that feed upon them but also help local fish stocks to recover

Most regions identified as highly polluted are enclosed areas of sea where ocean circulation is reduced, for which area-based measures can be applied

Because of such potential conflicts, governments may avoid designating certain areas which are earmarked for development in one way or another, and are reluctant to set aside areas of the size required to provide adequate protection for wide-ranging animals like marine mammals. A good example of where these tensions have arisen is in the North and Baltic Seas with the designation of SACs for harbour porpoise having to take account of a programme of offshore renewable energy development which may result in long-term disturbance following large-scale pile driving activities (Teilmann \& Carstensen, 2012; Mann \& Teilmann, 2013).

The desire to enlarge Marine Protected Areas for more effective protection, whilst managing multi-user activities, led to calls for marine spatial planning to be applied both within the coastal zone (Agardy, 2010; Agardy et al., 2011) and on the high seas (Ardron et al., 2008). Marine spatial planning (MSP), as defined by the Intergovernmental Oceanographic Commission (IOC) of UNESCO, is 'a public process of analysing and allocating the spatial and temporal distribution of human activities in marine areas to achieve ecological, economic, and social objectives that usually have been specified through a political process' (Ehler \& Douvere, 2007, 2009). They propose that characteristics of effective marine spatial planning should include that it is ecosystembased, place-based or area-based, integrated across sectors and agencies and among levels of government, adaptive in response to experience, strategic and anticipatory focusing upon the long-term, and participatory with stakeholders actively involved. The need to zone areas of sea for different uses, with some parts containing the more critical habitats for marine wildlife afforded full protection, has long been advocated (Batisse, 1990; Hyrenbach et al., 2000; Agardy, 2010).

MSP is viewed as a practical way to create and establish a more rational use of marine space and the interactions between its uses, balancing demands for development with the need to protect marine ecosystems, and to deliver on social and economic objectives in an open and planned way (Ehler \& Douvere, 2009). Thus, although it should be ecosystem-based (Crowder \& Norse, 2008; Gilliland \& Laffoley, 2008), MSP involves managing human activities in marine areas rather than a much more challenging target of managing ecosystems themselves (Ehler \& Douvere, 2009).

Planning is a dynamic process and needs to be responsive to changes as it evolves over time. This form of adaptive management needs to be incorporated into both MPAs and wider-scale ocean management. However, it requires regular monitoring both of human activities and marine organisms, so that actions are fully evidence-based.

The concept of MSP has been embraced by many countries in the last 10 years, and the means to achieve it continues to be refined (Douvere \& Ehler, 2009; Portman, 2011; Qiu \& Jones, 2013; Stelzenmüller et al., 2013), with attention paid to how best to integrate it into legislation (Schafer, 2009; Zervaki, 2015). A prerequisite is a good understanding of the spatial and temporal patterns of different human activities, and of marine animal taxa, through mapping supported by informed modelling. Significant progress has been made in the more accessible parts of the world to survey marine mammals and map their distributions and abundance. Ironically, it is actually the mapping of some human activities that is falling behind even in the most populated regions. Whereas tools such as AIS (Automatic Identification System) and VMS (Vessel Monitoring System) have enabled the plotting of vessel traffic, this is not possible for those not equipped with a transmitter (such as most vessels below $12 \mathrm{~m}$ length, which includes a large number of fishing and recreational craft). Thus, for the most part, maps of recreational and small boat fishing activities are lacking. Two other pressures 
upon marine mammals, that are by-products of human activities, are challenging to map: noise and pollutants. Continuous noise is mostly generated from shipping, and models now exist that will predict noise levels derived from plots of vessel movements using AIS/VMS. Impulsive noise (e.g. from seismic surveys, active sonar during military exercises, pile driving during marine construction) can also theoretically be measured but in practice this is not done on a routine basis. In Europe, ICES maintain an impulsive noise register (http://www.ices.dk/marine-data/data-portals/Pages/underwaternoise.aspx) from data submitted by member states, to support the EU Marine Strategy Framework Directive. This was started in February 2016 and still has many gaps. Mapping pollutant concentrations is even more challenging, and so far in NW Europe has relied upon regular sampling of particular indicator contaminants at 50 sites per OSPAR biogeographic region (OSPAR, 2010).

Marine mammal species vary in their sensitivity to different human pressures. They also vary in terms of life history characteristics, range and conservation status, all of which affect their vulnerability to particular pressures. These clearly need to be taken into consideration in the MSP process. An additional complication is how different human stressors may interact with one another, and the study of cumulative effects remains in its infancy (National Academies of Science, Engineering \& Medicine, 2017).

Finally, although top predators like marine mammals can serve as flagship species indicating the regional health of the marine environment, it is important to take consideration of other marine taxa that may have different ecological requirements. This need is reflected in the recent initiatives by the Convention on Biological Diversity to identify Ecologically or Biologically Significant Areas (EBSAs) and by IUCN for Key Biodiversity Areas (KBAs), even if they have no legal standing. At least they alert human society to Particularly Sensitive Sea Areas (PSSAs), a concept that the International Maritime Organisation (IMO) is already implementing within some MPAs through the compulsory routing of vessels. Such approaches need to be extended across a range of human pressures and then incorporated in international legislation.

\section{REFERENCES}

Agardy T. (1997) Marine Protected Areas and ocean conservation. London: Academic Press.

Agardy T. (2010) Ocean zoning: making marine management more effective. London: Earthscan.

Agardy T., Notarbartolo di Sciara G. and Christie P. (2011) Mind the gap: addressing the shortcomings of Marine Protected Areas through large scale marine spatial planning. Marine Policy 35, 226232

Ardron J., Gjerde K., Pullen S. and Tilot V. (2008) Marine spatial planning in the high seas. Marine Policy 32, 832-839.

Avila I.C., Kaschner K. and Dormann C.F. (2018) Current global risks to marine mammals: taking stock of the threats. Biological Conservation 221, 44-58.

Batisse M. (1990) Development and implementation of the biosphere reserve concept and its applicability to coastal regions. Environmental Conservation 17, 111-116.
Crowder L. and Norse E. (2008) Essential ecological insights for marine ecosystem-based management and marine spatial planning. Marine Policy 32, $772-778$.

Douvere F. and Ehler C.N. (2009) New perspectives on sea use management: initial findings from European experience with marine spatial planning. Journal of Environmental Management 90, 77-88.

Edgar G.J., Stuart-Smith R.D., Willis T.J., Kininmonth S., Baker S.C., Banks S., Barrett N.S., Becerro M.A., Bernard A.T.F., Berkhout J., Buxton C.D., Campbell S.J., Cooper A.T., Davey M., Edgar S.C., Försterra G., Galván D.E., Irigoyen A.J., Kushner D.J., Moura R., Parnell P.E., Shears N.T., Soler G., Strain E.M.A. and Thomson R.J. (2014) Global conservation outcomes depend on marine protected areas with five key features. Nature 506, 216-220. doi: 10.1038/ nature 13022

Ehler C. and Douvere F. (2007) Visions for a sea change. Report of the First International Workshop on Marine Spatial Planning. Intergovernmental Oceanographic Commission and Man and the Biosphere Programme. IOC Manual and Guides, 46: ICAM Dossier, 3. Paris: UNESCO

Ehler C. and Douvere F. (2009) Marine spatial planning: a step-by-step approach toward ecosystem-based management. Intergovernmental Oceanographic Commission and Man and the Biosphere Programme. IOC Manual and Guides No. 53, ICAM Dossier No. 6. Paris: UNESCO.

Evans P.G.H. (editor) (2008) Selection criteria for Marine Protected Areas for cetaceans. Proceedings of the ECS/ASCOBANS/ACCOBAMS workshop. ECS (European Cetacean Society) Special Publication Series, Volume 48. San Sebastian: European Cetacean Society, pp. $1-104$.

Gilliland P.M. and Laffoley D. (2008) Key element and steps in the process of developing ecosystem-based marine spatial planning. Marine Policy 32, 787-796.

Gjerde K.M. and Breide C. (editors) (2003) Towards a strategy for high seas Marine Protected Areas. Proceedings of the IUCN, WCPA and WWF Experts Workshop on High Seas Marine Protected Areas, 15-17 January 2003, Malaga, Spain. Gland: IUCN, 80 pp.

Gormley A.M., Slooten E., Dawson S., Barker R.J., Rayent W., du Fresne S. and Brager S. (2012) First evidence that marine protected areas can work for marine mammals. Journal of Applied Ecology 49, $474-480$.

Gubbay S. (ed.) (1995) Marine Protected Areas: principles and techniques for management. London: Chapman and Hall.

Halpern B.S., Walbridge S., Selkoe K.A., Kappel C.V., Micheli F., D’Agrosa C., Bruno J.F., Casey K.S., Ebert C., Fox H.E., Fujita R., Heinemann D., Lenihan H.S., Madin E.M.P., Perry M.T., Selig E.R., Spalding M., Steneck R. and Watson R. (2008) A global map of human impact on marine ecosystems. Science 319, 948-952.

Halpern B.S., Frazier M., Potapenko J., Casey K.S., Koenig K. and Longo C. (2015) Spatial and temporal changes in cumulative human impacts on the world's ocean. Nature Communications 6, 7615. doi: $10.1038 /$ ncomms 8615

Hooker S.K., Cañadas A., Hyrenbach K.D., Corrigan C., Polovina J.J. and Reeves R.R. (2011) Making protected area networks effective for marine top predators. Endangered Species Research 13, 203-218.

Hooker S.K. and Gerber L.R. (2004) Marine reserves as a tool for ecosystem-based management: the potential importance of megafauna. BioScience 54, 27-39.

Hoyt E. (2011) Marine Protected Areas for whales, dolphins and porpoises: a world handbook for cetacean habitat conservation and planning. London: Earthscan/Routledge, 477 pp. 
Hoyt E. (2017) Marine Protected Areas. In Würsig B., Thewissen J.G.M and Kovacs K.M. (eds) Encyclopedia of marine mammals, 3rd edition. San Diego, CA: Academic Press, pp. 369-380.

Hyrenbach K.D., Forney K.A. and Dayton P.K. (2000) Marine Protected Areas and ocean basin management. Aquatic Conservation Marine \& Freshwater Ecosystems 10, 435-458.

Kaschner K., Watson R., Trites A.W. and Pauly D. (2006) Mapping worldwide distributions of marine mammal species using a relative environmental suitability (RES) model. Marine Ecology Progress Series $316,285-310$

Kelleher G. (1999) Guidelines for Marine Protected Areas. Gland: IUCN, $107 \mathrm{pp}$.

Kelleher G., Bleakley C. and Wells W. (1995) A global representative system of Marine Protected Areas. Washington, DC: World Bank.

Mann J. and Teilmann J. (2013) Environmental impact of wind energy. Environmental Research Letters 8, 035001. doi: 10.1088/1748-9326/8/ 3/035001.

National Academies of Sciences, Engineering, and Medicine (2017) Approaches to understanding the cumulative effects of stressors on marine mammals. Washington, DC: The National Academies Press. doi: https://doi.org/10.17226/23479.

Notarbartolo di Sciara G., Hoyt E., Reeves R., Ardron J., Marsh H., Vongraven D. and Barr B. (2016) Place-based approaches to marine mammal conservation. Aquatic Conservation Marine \& Freshwater Ecosystems 26 (Suppl. 2), 85-100. doi: 10.1002/aqc.2642.

OSPAR Commission (2010) Quality status report 2010. London: OSPAR Commission, $176 \mathrm{pp}$.

Portman M. (2011) Marine spatial planning: achieving and evaluating integration. ICES Journal of Marine Science 68, 2191-2200.

Qiu W. and Jones P.J.S. (2013) The emerging policy landscape for marine spatial planning in Europe. Marine Policy 29, 182-190.

Ramesh R., Chen Z., Cummins V., Day J., D'Elia C., Dennison B., Forbes D.L., Glaeser B., Glaser M., Glavocic B., Kremer H., Lange M., Larsen J.N., Le Tissier M., Newton A., Pelling M., Purvaja R. and Wolanski E. (2015) Land-ocean interactions in the coastal zone: past, present \& future. Anthropocene 12, 85-98.

Reeves R.R. (2000) The value of sanctuaries, parks, and reserves (protected areas) as tools for conserving marine mammals. Report to the Marine Mammal Commission, Contract no. T74465385.
Roberts C.M. and Hawkins J.P. (200o) Fully protected marine reserves: a guide. Washington, DC: WWF-USA.

Salm R.V. and Clark J.R. (2000) Marine and Coastal Protected Areas: a guide for planners and managers, $3 \mathrm{rd}$ edn. Gland: IUCN.

Schafer N. (2009) The Integrated EU Maritime Policy and Maritime Spatial Planning - the way ahead. European Marine Sand and Gravel Group - a wave of opportunities for the marine aggregates industry. EMSAGG Conference, 7-8 May 2009, Frentani Conference Centre, Rome, Italy.

Stelzenmüller V., Breen P., Stamford T., Thomsen F., Badalamenti F., Borja Á., Buhl-Mortensen L., Carlström J., d'Anna G., Dankers N. Degraer S., Dujin M., Fiorentino F., Galparsoro I., Giakoumi S., Gristina M., Johnson K., Jones P.J.S., Katsanevakis S., Knittweis L., Kyriazi Z., Pipitone C., Piwowarczyk J., Rabaut M., Sørensen T.K., Van Dalfsen J., Vassilopoulou V., Vega Fernández T., Vincx M., Vöge S., Weber A., Wijmark N., Jak R., Qiu W. and Ter Hofstede R. (2013) Monitoring and evaluation of spatially managed areas: a generic framework for implementation of ecosystem based marine management and its application. Marine Policy 37, 149-164. doi: 10.1016/j.marpol.2012.04.012.

Teilmann J. and Carstensen J. (2012) Negative long term effects on harbour porpoises from a large scale offshore wind farm in the Baltic - evidence of slow recovery. Environmental Research Letters 7, 045101. doi: 10.1088/1748-9326/7/4/045101.

UNEP-WCMC, IUCN (2016) Update on global statistics from Protected Planet Report 2016. Cambridge and Gland: UNEP-WCMC, IUCN. Available at https://www.iucn.org/news/protected-areas/201612/updateglobal-statistics-protected-planet-report-2016 (accessed 26 March 2018)

Wilson B. (2016) Might marine protected areas for mobile megafauna suit their proponents more than the animals? Aquatic Conservation Marine and Freshwater Ecosystems 26, 3-8.

and

Zervaki A. (2015) Introducing maritime spatial planning legislation in the EU: fishing in troubled waters? Maritime Safety and Security Law Journal 1, 95-114.

\section{Correspondence should be addressed to:} P.G.H. Evans Email: peter.evans@bangor.ac.uk 